Tersedia Online di http://journal.unismuh.ac.id/index.php/otoritas

Otoritas : Jurnal Ilmu Pemerintahan, 7 (1), April 2017, 46-53

\title{
Politik Pemberantasan Korupsi di Indonesia
}

\author{
Suherry*) \\ Program Studi Ilmu Pemerintahan, STISIPOL Raja Haji, Jalan Raja Haji Fisabilillah No.48, \\ Pangkal Pinang, Kepulauan Riau, Indonesia \\ Diterima: 14 Februari 2017; Disetujui: 22 Maret 2017; Dipublikasikan: 14 April 2017
}

\begin{abstract}
This article discusses the politics of eradicating corruption in Indonesia. The most difficult problem in the running of the government process is due to the massive corruption, collusion and nepotism practices that have impacted widely on society. Corruption in the legal world is classified as an extraordinary crime because it not only harms the State's finances, but also practices violate the social and economic rights of society widely so that its eradication measures must also be done in an extraordinary way. That is what is disclosed in the consideration of the Law on the Eradication of Corruption. Through a juridical-empirical approach of this article, the question of corruption in Indonesia is well answered.
\end{abstract}

Keywords: Political; Law; Eradication Corruption

\begin{abstract}
Abstrak
Artikel ini membahas tentan politik pemberantasan korupsi di Indonesia. Masalah tersulit dalam berjalannya proses pemerintahan dikarenakan massifnya praktik korupsi, kolusi dan nepotisme yang meraja lela yang berdampak secara luas bagi masyarakat. Korupsi dalam dunia hukum sudah tergolong sebagai extra ordinary crime (kejahatan luar biasa) karena tidak hanya merugikan keuangan Negara, tetapi juga praktik tersebut melanggar hak-hak sosial dan ekonomi masyarakat secara luas sehingga tindakan pemberantasannya harus juga dilakukan dengan cara yang luar biasa pula. Begitulah yang diungkapkan dalam konsideran Undang-Undang Tentang Pemberantasan Tindak Pidana Korupsi. Melalui pendekatan yuridis-empiris, pertanyaan terkait pemberatasan korupsi di Indonesia terjawab dengan baik.
\end{abstract}

Kata kunci: Politik; Hukum; Pemberantasan Korupsi

Cara Penulisan Sitasi: Suherry, S. (2017). Politik Pemberantasan Korupsi di Indonesia. Otoritas : Jurnal Ilmu Pemerintahan, 7(1), 46-53.

${ }^{*}$ Penulis Korespondensi.

E-Mail : suherry89@gmail.com

Copyright @ 2017, Otoritas : Jurnal Ilmu Pemerintahan, p-ISSN: 2088-3706, e-ISSN: 2502-9320 
Tersedia Online di http://journal.unismuh.ac.id/index.php/otoritas

Otoritas : Jurnal Ilmu Pemerintahan, 7 (1), April 2017, 47

\section{Pendahuluan}

Secara harfiah korupsi merupakan sesuatu yang busuk, jahat, dan merusak. Menurut Poerwadarminta, korupsi ialah perbuatan yang buruk seperti penggelapan uang, penerimaan uang sogok dan sebagainya (Hamzah, 2008). Upaya preventif yang telah dilakukan oleh pemerintah untuk pemberantasan korupsi telah dimulai dengan UndangUndang Nomor 3 Tahun 1971 (Situmorang, 2014).

Diansyah (2009) mengemukakan apa saja masalah korupsi yang dilakukan oleh koruptor. Korupsi sebagai kebusukan ekonomi, kagagalan politik kolektif dan kejahatan luar biasa tidak mungkin dapat dilihat secara mikro dan sektoral dengan pengamatan yang melompat-lompat. Ia bukan kejahatan yang putus dan sekali selesai. Tetapi merupakan satu noktah hitam yang dibangun oleh sistem politik, kekuasaan yang terpusat pada segelintir orang, dan imperium bisnis yang menggunakan fasilitas kekuasaan untuk meraup keuntungan, baik di birokrasi, lembaga negara ataupun institusi politik diluar parlemen. Sehingga, rakyat menjadi korban.

Jika membicarakan tentang korupsi memang akan menemukan kenyataan semacam itu karena korupsi menyangkut segi-segi moral, sifat keadaan yang busuk, jabatan karena pemberian, faktor ekonomi dan politik, serta penempatan keluarga atau golongan kedalam kedinasan di bawah kekusaan jabatannya. Dengan demikian, secara harfiah dapat ditarik kesimpulan bahwa sesungguhnya istilah korupsi memiliki arti yang sangat luas. Dalam pandangan penulis, perilaku korup pada dasarnya disebabkan oleh beberapa faktor antara lain, tuntutan ekonomi, pengaruh lingkungan, lemahnya penegakan hukum dan kurangnya sosialisasi anti korupsi pada masyarakat.

Dari faktor tersebut diatas, salah satu faktor yang paling berperan aktif da- lam pemberantasan korupsi adalah faktor lemahnya penegakan hukum terhadap korupsi dan kurangnya sosialisasi sikap anti-korupsi di negeri ini. Terkait dengan upaya pemberantasan korupsi yang telah dilakukan di Indonesia, dapat dilihat bahwa upaya yang dilakukan masih cenderung parsial dan tidak memiliki desain strategi yang jelas sehingga dalam banyak hal tidak mampu mengurangi secara signifikan tingkat korupsi yang terjadi (Kurniawan, 2009).

Dalam upaya pemberantasan korupsi, diperlukan kerja sama semua pihak maupun semua elemen masyarakat, tidak hanya institusi terkait saja. Beberapa institusi yang diberi kewenangan untuk memberantas korupsi, antara lain Komisi Pemberantasan Korupsi (KPK), Kepolisian, Indonesia Corruption Watch (ICW), dan Kejaksaan.

Adanya KPK merupakan salah satu langkah berani pemerintah dalam usaha pemberantasan korupsi di Indonesia. Belakangan ini banyak dari kalangan masyarakat yang seringkali tidak puas dengan vonis hukuman yang diberikan kepada pelaku Tindak Pidana Korupsi. Mayoritas masyarakat yang tidak puas dengan vonis hukuman bagi pelaku korupsi beranggapan bahwa hukum tidak memberi jaminan keadilan, kepastian, dan kemanfaatan bagi masyarakat. Hukum senantiasa tajam kebawah dan tumpul keatas. Hal ini diakibatkan karena di dalam pengadilan sendiri terkadang terdapat juga praktik korupsi sehingga dalam penegakan hukum bagi pelaku korupsi juga kurang efektif. Jika dibandingkan dengan kasus pencurian yang dilakukan oleh masyarakat kalangan bawah seperti yang telah diberitakan sebelumnya yaitu nenek minah dalam kasus mencuri 3 (tiga) buah kakao sehingga harus dihukum dengan kurungan 1 bulan 15 hari (satu bulan lima belas hari) dan denda sebesar Rp. 1.000.000,- (satu juta rupiah), kemudian nenek asyiani yang dituduh mencuri kayu jati milik perhutani 
Tersedia Online di http://journal.unismuh.ac.id/index.php/otoritas

Otoritas : Jurnal Ilmu Pemerintahan, 7 (1), April 2017, 48

dan mendapat vonis hukuman 1 tahun penjara dengan masa percobaan 1 tahun 3 bulan dan denda Rp. 500.000.000,(lima ratus juta rupiah) subsider 1 hari hukuman percobaan, dan masih banyak lagi penegakan hukum yang tidak merata di negeri ini. Namun hukuman bagi pelaku tindak pidana korupsi sendiri lebih ringan dari apa yang tertera dalam Undang-Undang Tindak Pidana Pemberantasan Korupsi yang ancaman hukumannya adalah minimum 4 tahun penjara dengan denda minimum Rp. 200.000.000, - (dua ratus juta rupiah), dan maksimum seumur hidup bahkan hukuman mati dengan denda maksimum Rp. 1 Milyar sebagaimana yang dibunyikan dalam pasal 2 dan pasal 3 UU No. 31 Tahun 1999 Tentang Pemberantasan Tindak Pidana Korupsi. Namun demikian, apakah ancaman yang tertera dalam UndangUndang Tipikor tersebut telah membuat efek jera bagi pelaku tindak pidana korupsi ? dengan melihat maraknya kasus tersebut membuktikan bahwa UndangUndang Pemberantasan Tindak Pidana Korupsi tidak memberikan ancaman efek jera bagi pelakunya. Ada juga yang beranggapan bahwa pelaku Tindak Pidana Korupsi sebaiknya dimiskinkan dan sita asetnya untuk Negara. Lantas, dengan demikian hukuman yang bagaimanakah yang dapat menjerat pelaku tindak pidana korupsi dan menjadikan efek jera bagi pelanggarnya?.

\section{Metode Penelitian}

Pendekatan yang digunakan dalam penelitian ini adalah pendekatan yuridisempiris. Pendekatan yuridis (hukum dilihat sebagai norma atau das sollen), karena dalam membahas permasalahan penelitian ini menggunakan bahan-bahan hukum (baik hukum yang tertulis maupun hukum yang tidak tertulis). Pendekatan empiris (hukum sebagai kenyataan sosial, kultural atau das sein), karena dalam penelitian ini digunakan data primer yang diperoleh dari lapangan. Jadi, pendekatan yuridis empiris dalam penelitian ini maksudnya adalah bahwa dalam menganalisis permasalahan dilakukan dengan cara memadukan bahanbahan hukum yang merupakan data sekunder dengan data primer yang diperoleh di lapangan yaitu tentang analisis yuridis normatif tindak pidana korupsi.

\section{Hasil dan Pembahasan}

Rumusan unsur korupsi dalam Undang-Undang pemberantasan tindak pidana korupsi Nomor 31 Tahun 1999 masih belum memiliki kejelasan terkait apa yang dimaksud dengan unsur "menguntungkan diri sendiri" dan "memperkaya diri sendiri" seperti yang tertera dalam pasal 2 ayat (1) dan pasal 3 Undang-Undang pemberantasan tindak pidana korupsi. Pasal 2 ayat (1) dan pasal 3 adalah pasal favorit bagi penegak hukum, khususnya Komisi Pemberantasan Korupsi (KPK) dalam menjerat pelaku Tindak Pidana Korupsi. Adapun bunyi pasal 2 ayat (1) dan pasal 3 UndangUndang No. 31 Tahun 1999 yaitu:

Pasal 2 ayat (1) : "Setiap orang yang secara melawan hukum melakukan perbuatan memperkaya diri sendiri atau orang lain atau suatu korporasi yang dapat merugikan keuangan negara atau perekonomian negara, dipidana penjara dengan penjara seumur hidup atau pidana penjara paling singkat 4 (empat) tahun dan paling lama 20 (dua puluh) tahun dan denda paling sedikit Rp. 200.000.000,00 (dua ratus juta rupiah) dan paling banyak Rp. 1.000.000.000,00 (satu milyar rupiah)." Dari bunyi pasal yang demikian, jelas pasal 2 ayat (1) UU No. 20 Tahun 2001, menghendaki agar siapa saja yang terbukti melakukan tindak pidana korupsi, sebagaimana yang diatur dalam pasal 2 ayat (1) tersebut, akan dipidana dengan pidana penjara seumur hidup atau pidana penjara paling singkat 4 (empat) tahun dan paling lama 20 (dua puluh) tahun dan atau denda paling sedi- 
Tersedia Online di http://journal.unismuh.ac.id/index.php/otoritas

Otoritas : Jurnal Ilmu Pemerintahan, 7 (1), April 2017, 49

kit Rp. 200.000.000,00 (dua ratus juta) dan paling banyak Rp.1.000.000.000,00 (satu miliar rupiah). Berkaitan dengan sanksi bagi pelaku tindak pidana korupsi dalam pasal 2 ayat (1) UU No. 31 Tahun 1999, juga menegaskan bahwa apabila suatu tindak pidana korupsi dilakukan terhadap dana-dana yang diperuntukan bagi penanggulangan keadaan bahaya, bencana alam nasional, penanggulangan akibat kerusuhan sosial yang meluas, penanggulangan krisis ekonomi dan moneter, dan pengulangan tindak pidana korupsi, maka para pelaku tersebut dapat di pidana mati.

Kemudian pada pasal 3: "Setiap orang yang dengan tujuan menguntungkan diri sendiri atau orang lain atau suatu korporasi, menyalahgunakan kewenangan, kesempatan atau sarana yang ada padanya karena jabatan atau kedudukan yang dapat merugikan keuangan negara atau perekonomian negara, dipidana dengan pidana penjara seumur hidup atau pidana penjara paling singkat 1 (satu) tahun dan paling lama 20 (dua puluh) tahun dan atau denda paling sedikit Rp. 50.000.000,00 (lima puluh juta rupiah) dan paling banyak Rp. 1.000.000.000,00 (satu milyar rupiah)."

Pasal 3 UU Nomor 31 tahun 1999 ini memuat 3 (tiga) unsur yaitu: pertama, Dengan tujuan menguntungkan diri sendiri atau orang lain atau suatu korporasi; kemudian, Menyalahgunakan kesempatan atau sarana yang ada padanya karena jabatan atau kedudukan; dan yang terakhir adalah unsur Yang dapat merugikan keuangan negara atau perekonomian Negara. Jika dilihat perbedaan antara unsur pada pasal 2 dan pasal 3 tersebut, keduanya hampir mirip akan tetapi berbeda. Persamaan antara kedua pasal tersebut terletak pada unsur merugikan keuangan atau perekonomian Negara, sementara perbedaannya adalah terletak pada unsur perbuatan memperkaya diri sendiri dan menguntungkan diri sendiri. Lantas dengan demikian, muncul pertanyaan mengapa rumusan ketentuan dalam Pasal 2 dicantumkan kalimat "memperkaya" sedangkan di dalam Pasal 3 dicantumkan kalimat "menguntungkan"?. Jika berpikir secara logika umum, seorang pejabat publik/Pegawai Negeri Sipil yang diangkat oleh Negara adalah bertujuan untuk mengabdi kepada bangsa dan negara tanpa pamrih, dan tidak ada diniatkan untuk memperkaya diri sendiri. Tujuan memperkaya lazimnya merupakan usaha dari pihak perorangan swasta, dan selalu berharap akan lebih kaya lagi. Akan tetapi, apakah tidak dimungkinkan seorang pegawai negeri sipil itu dapat melakukan perbuatan memperkaya diri ?. kemudian Selanjutnya, mengapa ancaman pidana minimum di dalam Pasal 2 lebih berat (minimum 4 tahun) dari ancaman pidana dalam Pasal 3 (minimum 1 tahun)?.

Selain itu, tidak hanya pasal 2 dan pasal 3 saja yang memiliki permasalahan untuk menjerat pelaku Tindak Pidana Korupsi, tetapi juga terdapat pula pada pasal 5 ayat (2) dan pasal 12 huruf a UU No. 20 Tahun 2001 Tentang Perubahan Atas UU No. 31 Tahun 1999 Tentang Pemberantasan Tindak Pidana Korupsi. Berdasarkan hemat saya, kedua pasal tersebut yakni pasal 5 ayat (2) dan pasal 12 huruf a merupakan pasal yang diadopsi dari pasal 419 KUHP (Kitab UndangUndang Hukum Pidana) yang didalamnya terdapat unsur kesengajaan (dolus), namun memiliki ancaman hukuman yang berbeda yakni penjara paling singkat 1 (satu) tahun dan paling lama 5 (lima) tahun dan/atau pidana denda paling sedikit Rp. 50.000.000,00 (lima puluh juta rupiah) dan paling banyak Rp. 250.000.000,00 (dua ratus lima puluh juta rupiah) untuk pasal 5 ayat (2), dan pidana penjara seumur hidup atau pidana penjara paling singkat 4 (empat) tahun dan paling lama 20 (dua puluh) tahun dan pidana denda paling sedikit $\mathrm{Rp} 200.000 .000,00$ (dua ratus juta rupiah) dan paling banyak Rp 1.000.000.000,00 (satu miliar rupiah) untuk ancaman pidana pada pasal 12 di da- 
Tersedia Online di http://journal.unismuh.ac.id/index.php/otoritas

Otoritas : Jurnal Ilmu Pemerintahan, 7 (1), April 2017, 50

lam UU Nomor 20 Tahun 2001 Tentang Perubahan Atas Undang-Undang Nomor 31 Tahun 1999 Tentang Pemberantasan Tindak Pidana Korupsi. Padahal, kedua pasal tersebut memiliki unsur yang berbeda dan merupakan satu kategori kejahatan yang sama yaitu penyuapan pasif. Pasal 5 ayat (2) jika ditelaah adalah kategori unsur kesengajaan (dolus), sementara pasal 12 huruf a selain terdapat unsur kesengajaan (dolus) terdapat pula unsur kelalaian (culpa). Anehnya, delik culpa (kelalaian) lebih berat ancaman hukumannya ketimbang delik dolus (kesengajaan).

Secara teori hukum pidana, kesengajaan atau dolus diartikan sebagai "het teweegbrengen van verboden handeling willens en wetens" atau melakukan suatu perbuatan yang terlarang secara dikehendaki dan dimengerti. Artinya, apabila seseorang pada waktu ia melakukan suatu tindakan untuk menimbulkan suatu akibat yang terlarang, menyadari bahwa akibat tersebut pasti akan timbul ataupun mungkin dapat timbul karena tindakan yang akan atau sedang ia lakukan, sedangkan timbulnya akibat tersebut memang ia kehendaki. Sementara culpa atau kelalaian oleh ilmu pengetahuan dan yurisprudensi ditafsirkan sebagai "een tekfort aan voorzienigheid" yang berarti suatu kekurangan untuk melihat jauh kedepan tentang kemungkinan timbulnya akibat-akibat hukum atau "een manco aan voorzichtigheid" yang berarti suatu sikap yang kurang berhati-hati. Dengan demikian, kedua penjelasan tersebut jelas dapat kita lihat terhadap hukuman yang sepantasnya berat dan sepantasnya ringan. Menurut pendapat saya, berdasarkan kajian dolus dan culpa tersebut, maka dolus lah yang harusnya tercantum ancaman hukuman berat, sedangkan culpa harus diancam dengan hukuman ringan ataupun sedang. Karena culpa merupakan suatu wilsfout atau suatu kesalahan kehendak yang berakibat hukum, dimana pelakunya tidak mengingikan terjadinya perbuatan itu namun atas dasar keadaan tertentu yang menyebabkan keteledoran seseorang menjadikannya berakibat hukum.

Kemudian terkait efektifitas hukuman bagi koruptor, antara hukuman mati dan/atau dimiskinkan. Manakah yang lebih efektif ?. Pidana mati tercantum pada pasal 10 KUHP berada pada posisi peletakan ancaman hukuman paling atas dan merupakan pidana pokok, artinya pidana mati dapat diterapkan untuk kasuskasus kejahatan yang berat seperti terorisme. Namun apakah tidak dimungkinkan bagi pelaku Tindak Pidana Korupsi ? jawabnya, mungkin saja. Karena korupsi digolongkan sebagai kejahatan luar biasa (extra ordinary crime) (Toule, 2013).

Tidak saja karena modus dan teknik yang sistematis, akibat yang ditimbulkan kejahatan korupsi bersifat paralel dan merusak seluruh sistem kehidupan, baik dalam bidang ekonomi, politik, sosialbudaya dan bahkan sampai pada kerusakan moral serta mental masyarakat. Kerugian secara ekonomi dari korupsi, jelas dapat dirasakan oleh masyarakat, tercermin dari tidak optimalnya pembangunan ekonomi yang dijalankan, selain itu hasil yang diperoleh dari berbagai aktifitas ekonomi bangsa, seperti pajak, menjadi jauh lebih kecil dari yang seharusnya dicapai.

Kerugian dalam bidang politik, praktek korupsi menimbulkan diskriminasi pelayanan publik ataupun diskriminasi penghargaan terhadap hak-hak politik masyarakat. Sedangkan kerugian dalam bidang sosial-budaya dan moral, praktek korupsi telah menimbulkan "penyakit" dalam masyarakat, bahwa perbuatan tersebut seakan dianggap sebagai perbuatan yang halal dan wajar. Hamzah (2008) juga berpendapat bahwa pemberantasan korupsi tidak hanya bertumpu pada pembaharuan Undang-Undang, namun harus terdapat upaya lebih dari itu.

Jika satu kasus korupsi dan 
pelakunya dijatuhi hukuman seumur hidup ataupun hukuman mati, maka akan berakibat pada tanggungan Anggaran Pendapatan Belanja Negara yang besar. contoh misalnya, pada kasus korupsi eks presiden Partai Kesejahteraan Sosial Luthfi Hasan Ishak ataupun eks bendahara Umum Partai Demokrat Nazarudin yang dijatuhi hukuman masing-masing seumur hidup, ini akan mengakibatkan pembebanan APBN (Anggaran Pendapatan Belanja Negara) beberapa ratus juta untuk satu orang terpidana seumur hidup pelaku korupsi di dalam sel tahanan karena harus memberi jaminan Hak Asasi Manusia di dalam sel tahanan. Belum lagi pengeluaran Anggaran Pendapatan Belanja Negara (APBN) untuk pembangunan nasional dengan jangka tertentu ditambah lagi ongkos pengiriman, persiapan penguburan, dan pemakaman narapidana yang meninggal di dalam Lembaga Pemasyarakatan yang telah menjalani vonis seumur hidup. Atau pun seperti kasusnya Labora Sitorus yang telah melarikan diri dari Lembaga Pemasyarakatan Sorong, Papua Barat. Pembebanan inilah yang patut diperhatikan oleh hakim dalam memutus lamanya masa tahanan bagi terpidana korupsi. Nah, bagaimana pula jika seandainya pelaku Tindak Pidana Korupsi itu dimiskinkan?.

Pada dasarnya, hukuman bagi pelaku Tindak Pidana Korupsi adalah termasuk hukuman yang berganda atau ber double-double atau dalam bahasa hukum dikenal dengan istilah subsideritas, dimana setelah pelaku korupsi tersebut diperiksa dan diadili, nyata-nyata hukumannya itu seolah-olah para koruptor itu sudah dimiskinkan dengan sendirinya. Hal ini terlihat dari adanya pembekuan aset-aset para pelaku korupsi, baik oleh juru sita pengadilan maupun penyidik ketika dalam proses penyidikan. Belum lagi ditambah dengan hukuman penjara yang ditentukan Undang-Undang Tindak Pidana Korupsi dan kewajiban membayar denda ganti kerugian Negara sekian juta atau miliar serta pengembalian uang Negara sebanyak yang telah dikorupsinya. Jika dikaji secara hukum, memiskinkan tersangka kasus korupsi telah tergolong pelanggaran terhadap asas presumption of innocent (praduga tidak bersalah) sebagaimana yang telah diatur dalam pasal 8 ayat (1) UU No. 48 Tahun 2009 Tentang Kekuasaan Kehakiman juncto penjelasan umum butir 3 huruf c Kitab UndangUndang Hukum Acara Pidana (KUHAP) yang menegaskan bahwa "Setiap orang yang disangka, ditangkap, ditahan, dituntut, atau dihadapkan di depan pengadilan wajib dianggap tidak bersalah sebelum ada putusan pengadilan yangmenyatakan kesalahannya dan telah memperoleh kekuatan hukum tetap." Jika tersangka kasus korupsi dalam masa penyidikannya saja sudah dilakukan penyitaan aset, kemudian ditambah lagi dengan putusan pengadilan yang harus membayar ganti kerugian dan perampasan serta penyitaan barang-barang tertentu, sejatinya para penegak hukum telah merubah paradigma asas praduga tidak bersalah menjadi asas praduga bersalah. Konsep gagasan hukuman seperti ini layaklah untuk difikirkan terlebih dahulu untuk memiskinkan pelaku korupsi sehingga tidak menimbulkan polemik kembali dikalangan masyarakat selaku korban, pengamat, dan politik dalam hal ini pemerintah bersama-sama DPR dalam membuat, membahas, dan mengesahkan Undang-Undang. Untuk itu perlulah kita fikir bersama hukuman seperti apakah yang akan membuat efek jera bagi pelaku Tindak pidana korupsi. Kalau penjara seumur hidup, hukuman mati, pengembalian uang kerugian Negara (atau hukuman beruntun) yang telah dilancarkan penegak hukum tidak juga mengurangi praktek KKN di negeri ini, maka hukuman apa lagi yang harus digunakan dengan memperhatikan asas-asas hukum yang berlaku, perekonomian demi pembangunan nasional dan kesejahteraan masyarakat. Karena konsep Negara 
Tersedia Online di http://journal.unismuh.ac.id/index.php/otoritas

Otoritas : Jurnal Ilmu Pemerintahan, 7 (1), April 2017, 52

hukum pada dasarnya adalah menjunjung tinggi hukum, persamaan setiap orang dihadapan hukum dan kesejahteraan masyarakat.

Selain itu Berdasarkan keterangan dan data kementerian sekretariat negara Republik Indonesia, bahwa untuk menanggulangi perilaku tindak pidana korupsi dapat dilakukan dengan cara metode pencegahan dan penindakan sebagaimana yang dikatakan oleh wakil ketua KPK Mochammad Jasin pada saat jumpa pers di gedung KPK beberapa bulan lalu. Tak hanya mochammad jasin, pimpinan KPK sebelumnya pun telah membunyikan hal yang senada dengan wakil ketua KPK sekarang ini melalui juru bicara KPK johan budi.

Dalam melakukan pemberantasan ini, berbagai upaya telah dilakukan pemerintah melalui kebijakankebijakannya. Salah satu diantaranya dengan pembentukan Komisi Pemeriksa Kekayaan Penyelenggara Negara (KPKPN) melalui Undang-Undang Nomor 28 Tahun 1999 tentang Penyelenggaraan Negara yang Bersih KKN dibentuklah Komisi Pemeriksa Kekayaan Penyelenggara Negara (KPKPN). Dalam tugasnya KPKPN berhasil meletakkan landasan yang baik bagi mekanisme pelaporan kekayaan penyelenggara negara secara komprehensif pada era reformasi. Dalam tugasnya KPKPN berhasil meletakkan landasan yang baik bagi mekanisme pelaporan kekayaan penyelenggara negara secara komprehensif. Selanjutnya pada era sekarang telah hadir lembaga anti rasuah yang baru yang tugas dan wewenangnya diberikan sesuai UU No. 30 Tahun 2002 Tentang Komisi Pemberantasan Korupsi. Dalam UU tersebut, KPK diberikan kewenangan penyadapan tanpa meminta izin langsung oleh kepolisian negara republik indonesia, kejaksaan dan Mahkamah Agung. Melalui kewenangan inilah, KPK disebut lembaga anti rasuah dan lembaga super body,. KPK sendiri memiliki bidang khusus yang menangani pencegahan dan penindakan.

\section{Kesimpulan}

Harus diakui bahwa faktor yang menjadi penyebab utama terjadinya perilaku korupsi diantaranya, tuntutan ekonomi, pengaruh lingkungan, lemahnya penegakan hukum dan kurangnya sosialisasi anti-korupsi di masyarakat. Dalam upaya pemberantasan korupsi, diperlukan kerja sama semua pihak maupun semua elemen masyarakat, tidak hanya institusi terkait saja. Beberapa institusi yang diberi kewenangan untuk memberantas korupsi, antara lain KPK, Kepolisian, Indonesia Corruption Watch (ICW), dan Kejaksaan.

Akibat korupsi adalah ketidak efisienan, ketidakadilan, rakyat tidak mempercayai pemerintah, memboroskan sumber-sumber negara, tidak mendorong perusahaan untuk berusaha terutama perusahaan asing, ketidakstabilan politik, pembatasan kebijaksanaan pemerintah dan tidak represif. Salah satu diantaranya dengan pembentukan Komisi Pemeriksa Kekayaan Penyelenggara Negara (KPKPN) melalui UU no. 28/1999 tentang Penyelenggaraan Negara yang Bersih KKN dibentuklah Komisi Pemeriksa Kekayaan Penyelenggara Negara (KPKPN) dan selanjutnya pada era sekarang telah hadir lembaga anti rasuah yang baru yang tugas dan wewenangnya diberikan sesuai UU No. 30 Tahun 2002 Tentang Komisi Pemberantasan Korupsi. Dalam UU tersebut, KPK diberikan kewenangan penyadapan tanpa meminta izin langsung oleh kepolisian negara republik indonesia, kejaksaan dan Mahkamah Agung.

\section{Ucapan Terima Kasih}

Ucapan terima kasih, kami haturkan kepada Civitas Akademika STISIPOL Raja Haji, Pangkal Pinang atas bantuan dan dukungan selama proses penelitian hingga publikasi sebagai bentuk bakti Tri Dharma Pendidikan. 
Tersedia Online di http://journal.unismuh.ac.id/index.php/otoritas

Otoritas : Jurnal Ilmu Pemerintahan, 7 (1), April 2017, 53

\section{Daftar Pustaka}

Hamzah, A. (2008). Pemberantasan Korupsi Melalui Hukum Pidana Nasional dan Internasional. Jakarta: Rajawali Pers.

Diansyah, F. (2009). Senjakala Pemberantasan Korupsi; Memangkas Akar Korupsi dari Pengadilan Tipikor. Jurnal Konstitusi, Juli, 6 (2), 7-42.

Situmorang, M. (2014). Harmonisasi Hukum Nasional Di Bidang Korupsi dengan United Nations Convention Against Corruption. Jurnal Rechts Vinding: Media Pembinaan Hukum Nasional, 3(3), 329 $-346$.
Toule, E. R. (2013). Eksistensi Ancaman Pidana Mati Dalam UndangUndang Tindak Pidana Korupsi. Jurnal Hukum PRIORIS, 3(3).

Kurniawan, T. (2011). Peranan Akuntabilitas Publik dan Partisipasi Masyarakat dalam Pemberantasan Korupsi di Pemerintahan. Bisnis \& Birokrasi Journal, 16(2). 